\title{
A STUDY OF FACTOR AFFECTING THE SOFTWARE APPLICATION DEVELOPMENT IN INDONESIAN CREATIVE INDUSTRY
}

\author{
Adhi Nugroho Chandra'; Yohannes Kurniawan² \\ ${ }^{1,2}$ Information Systems Department, School of Information Systems, BINUS University \\ Jl.KH.Syahdan no.9 Kemanggisan Palmerah Jakarta Indonesia \\ 1inux77@yahoo.com; '2ykurniawan@binus.edu
}

\begin{abstract}
The creative industries promising opportunities, especially the interactive game business. creative industries is still undeveloped, but lately has been showing its contribution to the economic development of Indonesia. Implementation of the Information and Communication Technology (ICT) strategy is a new discourse that can provide great opportunities for the entrepreneurial. This study aims to reveal the level of implementation of ICT strategies, the role of government influence on the development of business, industry conditions as well as the existing value chain in the interactive games industry. Type of research conducted by descriptive research, qualitative analysis was based on the findings of desk research / literature, interview sources, and the researcher's own knowledge. Level of subjectivity can be minimized with the help of quantitative analysis and the selection of competent resource persons in the field interviews. Secondary data obtained from the creative economy planning books in 2025, which was published by the Ministry of Commerce of the Republic of Indonesia. Based on the research results, it is concluded that the implementation of ICT strategies by entrepreneurs in the interactive games industry is still less, and this is partly because in general the industry is still small-scale and micro enterprises, mash the industry is relatively new in the world of business, and entrepreneurs are still concentrating the creation, production, and distributio, commercialization are being developed. In general, interactive games industry is growing. In the future, need to research business model and business strategy, so it would complement the models developing strategy in the game interactive industry.
\end{abstract}

Keywords: entrepreneurs, creative industry, interactive games, ICT Strategy, value chain

\begin{abstract}
Industri kreatif menjanjikan banyak kesempatan, khususnya bisnis permainan interaktif. Industri kreatif masih belum dikembangkan, tetapi belakangan sudah menunjukan kontribusinya pada perkembangan ekonomi Indonesia. Penerapaan strategi TIK merupakan sebuah pendekatan baru yang dapat memberikan kesempatan yang sangat baik untuk pengusaha. Penelitian ini bertujuan untuk mengungkapkan tingkatan dari implementasi strategi TIK, peran pemerintah dalam mempengaruhi perkembangan bisnis, kondisi industry sebagaimana sebagai keluaran dari rantai nilai industri permainan interaktif. Jenis penelitian adalah penelitian deskriptif, analisis kualitatif didasarkan penemuan pada penelitian pustaka, wawancara, dan pengetahuan peneliti sendiri. Tingat subjektifitas bias diminimalisasi dengan bantuan analisis kuantitatif dan pemilihan narasumber yang kompeten. Data sekunder diambil dari buku perencanaan ekonomi kreatid 2025 yang diterbitkan oleh kementrian perdagangan |Republik Indonesia. Berdasarkan hasil penelitian, implementasi strategi TIK oleh pengusaha di inustri game interaktif masih sedikit, dan sebagian besar pengusaha masih dalam skala UKM, dan pengusaha masih berkonsentrasi di kreasi, produksi dan untuk distribusi dan komersialisasi masih dalam pengembangan. Secara umum industry permainan interaktif bertumbuh. Kedepannya, dibutuhkan penelitian menegnai model bisnis dan strategy bisnis, yang akan melengkapi model strategi pengembangan bisnis permainan interaktif.
\end{abstract}

Kata kunci: pengusaha, industri kreatif, permainan interaktif, strategi TIK 


\section{INTRODUCTION}

Technological developments, especially in the modern and globalization era, require resources, both individuals and organizations, to master and be able to compete. In addition, the crisis situation that occurred recently made a lot of workers who lost their jobs and the company can no longer continue its business activities. The presence of creative industries in Indonesia provides a great opportunity for people who are struggling to get through the global financial crisis and for many people who are also promoting the entrepreneurship. So the situation is not accidental, but rather an opportunity and a challenge for all to be able to get into creative industries by becoming an entrepreneur.

On the other side, information technology has become an integral part of modern society, especially those living in big cities. Ranging from mobile phones to computers, Internet is a tool to support the activities of life, even a lifestyle. An example is a social network in the virtual world, facebook, that becomes people's favourite site ranging from middle-aged people, professionals, housewives, students, teenagers, even to toddlers who incidentally have not mastered the computer. Another example is the blackberry smart phone, a unique phenomenon in Indonesia. Gadgets/smart phone have made other manufacturers overwhelmed, so they must produce a product that has features resemble or at least with facebook apps in it.

This phenomenon is captured by some people as an opportunity since many people try online transactions on the internet for offering goods or services via the website, blogs, forums, social networking, and others. Although they are not professionals, such efforts can teach them the entrepreneurial spirit.

Interactive games becomes people's favorites since its emergence, the first interactive game is the name Missile Simulator Game that is invented by Thomas T. Goldsmith Jr. and Estle Ray Mann on a cathode ray Fund. During its development, the look and shape of the game is getting better through gaming technology curve. As the 70s is the golden arcade video games, it is marked by the emerging era of the first generation of games consoles, mainframe computers, home computers and the second generation game consoles emerged at the end of 70's. In the 80s, as a stream of innovative, computer game has emerged at the same time as the beginning of the online game. In addition, it also appears Handheld LCD games and third-generation game consoles. In 90s, it is marked by the emergence of mobile phone gaming, fourth generation consoles (1987-1999) (16-bit), fifth generation consoles (1993-2006, 32 and 64-bit). The 2000's is marked by the emergence of Mobile games, sixthgeneration consoles, prominent online games, increased casual PC games, as well as the seventhgeneration consoles (since 2004).

So why now this game (interactive games) is loved by people (old and young)? The most common reason is since the games is entertaining. For some other reasons, it fills spare time and as an activity, it may have little value but the main reason is to educate people. Game could be a picture of cultures, technological advances and even social criticism, for example is the emergence of a shoethrowing game to a president, after the embarrassing incident. There is an interesting phenomenon in recent years, the influence of game can make people stay awake or even stealing possessions to be able to play a game. However, there are game developers from national to international level that can gain money from the game.

Game development is very wide, not just merely entertainment factor, education, even to the economic factors. The new business models emerging from the game, now has developed into a lease, even for free. So how gaming companies earn money? Game may be free, but additional features can only be obtained after removing the extra cost. New games can be played after paying a sum of money 
to buy the vouchers as the right to play in the game. As a country that is quite keep up with technology, Indonesia has the ability to take part in the gaming industry world. In Indonesia, production games is a part of creative industry in interactive game business group.

Then how the latest developments of the homeland gaming industry? And how the characteristics of game makers in the homeland? Is it limited to the level of a hobby or have people started to see it as an industry?

The Government believes that a creative industry is an industry that can survive in the crisis, be labor-intensive and be able to grow from small to medium scale. In Indonesia creative economic development plan in 2025, the government, in this case the Commerce Department revealed numerous huge potential of the creative industries. The mission that has to be achieved in 2015 is empowering human resources Indonesia national development as primary of capital and the vision of the creative economy Indonesia 2025 is the quality of Indonesian people life and creative looks in the eyes of the world will be achieved.

This research was conducted in an attempt to answer several questions: (1) Do ICT strategies help entrepreneurs interactive game industry/game in business? (2) Have the government helped the creation and development of the game technopreuner in Indonesia? (3) Is technopreuner has become a large-scale industrial entrepreneurship?

This study aims to reveal the level of implementation of ICT strategies by entrepreneurial interactive games and the length of the business life, study the role of government influence on the development of interactive gaming business and uncovering the interactive games industry conditions in Indonesia. Learning the value chain in the interactive games industry. The benefit of this research is to provide an overview of the managerial impact on the strategic use of IT in the creative industries, provide an overview of the plan and the government's strategy to develop the business climate of creative industries in particular interactive game business and provide an overview of potential business models that can be developed from the interactive game business.

\section{Literature Review}

Entrepreneurship can be grouped in various ways. Winarto (2003) classify entrepreneurial activities into two, namely entrepreneurship for a business opportunity (entrepreneurial activity by opportunity) and entrepreneurial for no other alternative but to perform certain business activities. Previously people thought that entrepreneurship is innate talent (entrepreneurship are born grout made) and it is only obtained from the practice. However, entrepreneurship is now a discipline that can be learned and taught.

Entrepreneurship is the result of a disciplined, systematic process of applying creativity and innovation to meeting the needs and opportunities in the market. In Indonesia, a new study of entrepreneurship is limited to a particular school or college course. In line with the developments and challenges such as the economic crisis, understanding entrepreneurship both through formal education and training at all levels of society will develop entrepreneurship.

Style innovation consists of two-sided terms, namely, the technical world and business world. From the technical side, it is called the invention of technological change and however, when business is involved in the effort of the invention, it is called innovation. The real innovation comes to a company that exists inside and outside of the company. Effective innovation is a simple, focused, accept what people say, specific, clear, starting small and design applications carefully. To be able to analyze business opportunities, entrepreneurs must know a few tools such as SWOT analysis, Competitive Profile Matrix, and BCG Matrix. There are three ways can be done to start a business or 
enter a business world and they are pioneering new business (starting), acquisition of a company (buying) and management collaboration (franchising).

Strength of small businesses have a number of advantages, of having the freedom to act, flexible and not easily shaken, while some drawbacks are in the form of structural weaknesses and focus. The main focus in developing this entrepreneurial is emphasized on the creation of added value to gain competitive advantage through the development of specific capabilities (entrepreneurship) to small enterprises that are not longer operate through monopoly market power strategy and government facilities.

Amid the global economic downturn and the threat of layoffs today, the Minister of Trade Mari Elka Pangestu confirmed the development of the creative industries have been able to absorb the 4.9 million workers and contributed an average of 6.3 percent of Gross Domestic Product in 2008. This data is based on studies of Creative Industry Development Plan that is being finalized Commerce Department. (sampoerna foundation, 2009).

The creative economy businesses cannot grow by itself. It takes three stakeholders known as the triple helix; businessmen, intellectuals, and government in a holistic, concrete and sustainable networking. Entrepreneurs in this case is a group that empower the creative economy businesses, the intellectuals who produce creative works of both traditional and modern-culture, as well as the government in this case to protect the stakeholders and the create policies to the business of creative economic development in Indonesia. Creative industry is a major pillar in developing the creative economy sector that provides a positive impact for the life of the nation. The government believes that creative industry is an industry that can survive in the crisis, labor-intensive, able to grow from small to medium scale. (Kelompok Kerja Indonesia Design Power - Departemen Perdagangan, 2008)

The definition is based on UK DCMS Task Force 1998: "Creative Industries roommates as those industries have their origin in individual creativity, skill and talent, and roommates have a potential for wealth and job creation through the generation and exploitation of intellectual property and content". As one of the creative industries business groups, interactive games can be described as a creative activity related to the creation, production, and distribution of computer and video games that are fun, agility, and education. Ward and Peppard (2002) outlines at least three strategies that can be used, this strategies are also in line with Porter's Generic Strategies, that is low-cost strategies (lowcost) prior to the organization that is identified as the lowest cost approach in business activities to minimize indirect costs and support management with a detailed report on all aspects of the cost.

Differentiation Strategy is aimed at a broad market that involves the creation of a product or service that is unique throughout the industry. Differentiation is a viable strategy for above average profits in a particular business because the resulting brand loyalty lowers the price-sensitive customers. Increased costs can usually be charged to the buyer. Buyer loyalty can also serve as a barrier to entry of new firms. Differentiation strategy is more likely to produce higher returns than low cost strategy because differentiation creates a barrier to entry the better.

Niche/Focus Strategy allow the company's strategy to concentrate on a few selected target markets. It is also called a niche strategy or segmentation strategy. It is hoped that by focusing marketing efforts on one or two narrow market segments and tailor marketing to specific markets, firms can better meet the needs of the target market. Companies usually to gain competitive advantage through product innovation and may or brand marketing rather than efficiency. It is most suitable for relatively small firms but can be used by any company. The focus of the strategy should be directed to market segments that are less vulnerable to substitutes or where competition is weakest to earn above average return on investment. There are three ways to become a market leader, the operation excellence, customer intimacy, product leadership. 
The Boston Matrix (BCG Matrix Business) is an example of a technique for ICT strategy. (Manktelow, 2010). There are four categories: (1) Star, a strong market position in high-growth markets. (2) Cashcow, strong market position in a low growth market. (3) Wildcat, a low market share in high-growth markets. (4) Dog, a weak position in the growing markets low/declining.

Porter five forces, which has more than 20 years and still relevant, namely: bargaining power of suppliers, bargaining power of buyers, treat of new entrants, threat of substitute products or services, rivalry among existing competitors.

\section{METHOD}

This study discusses and examines the application of information systems strategy on value chain business group interactive game. Discussion, in the interactive game business climate, should be positioned and treated as a part of government policy, in this case is the creator of interactive gaming/game. So, this study is to evaluate policies, especially evaluation of government policies on the creative industries are relatively new, and it is hoped will be able to reveal the clarity of the business climate relationships in the game development industry in the country.

The research is conducted by descriptive research. Descriptive research is a research that provides an overview or description of an existing state as clearly as possible without the treatment of the object under study. Qualitative analysis was based on the findings of desk research/ literature, interview and the researcher's knowledge. Level of subjectivity can be minimized with the help of quantitative analysis and the selection of competent resource persons in the field interviews. (Moloeng, 2004). Secondary data is obtained from the creative economy planning books in 2025, which was published by the Ministry of Commerce of the Republic of Indonesia.

\section{RESULTS AND DISCUSSION}

Number of creative workers is still low if it is compared to other sectors but the quality can still be improved. The amount of labor involved in the creative industries sector in 2006 based on studies in 2007 about mapping the creative industries trade department of the Republic of Indonesia was about 4.9 million workers. Being creative talent gets interesting. Openness of society in terms of media is a positive impact on the growth of space for expression and creativity. Public notice in the source of arts entertainment profession as something attractive, not only economically but also views of public appreciation.

Entrepreneurship began to grow. Besides creative labor, entrepreneurs also play very important role in the growth of the creative industries. Slowly, entrepreneurship started to become an attractive profession option (Especially for highly educated). Although people still have the mindset preferences worked as private employees or civil servants. This situation posses for the entrepreneurial spirit to grow more fertile but implies hope for change in the public driving force for the growth of entrepreneurship.

Potential market in the domestic and overseas is still huge. Domestic potential market has not been served optimal because of people's appreciation in art, culture, design is still lacking. Geographic location of the market is still difficult to reach. Reaching into overseas markets and understanding

consumer behavior should be improved. Foreign consumers have relatively high appreciation of the products/services that have local content and artistic merit. 
Interactive game industry promises a sizeable income, and makes an interesting industry to place a career.

\begin{tabular}{|l|l|r|}
\hline \multicolumn{2}{|c|}{ No Creative Industry Group } & Average (Thousand Rp.) \\
\hline $\mathbf{1}$ & Interactive Game & 133.779 \\
\hline $\mathbf{2}$ & Architecture & 131.355 \\
\hline $\mathbf{3}$ & Computer Services \& Software & 131.355 \\
\hline $\mathbf{4}$ & Research \& Development & 131.355 \\
\hline $\mathbf{5}$ & Advertising & 131.355 \\
\hline $\mathbf{6}$ & Publishing \& Printing & 53.607 \\
\hline $\mathbf{7}$ & Music & 40.586 \\
\hline $\mathbf{8}$ & Design & 20.593 \\
\hline $\mathbf{9}$ & Fashion & 16.523 \\
\hline $\mathbf{1 0}$ & Handicraft & 16.174 \\
\hline $\mathbf{1 1}$ & Film, Video, \& Photography & 14.949 \\
\hline $\mathbf{1 2}$ & Art goods Market & 14.679 \\
\hline $\mathbf{1 3}$ & Art Show & 14.612 \\
\hline $\mathbf{1 4}$ & Television \& Radio & 14.612 \\
\hline
\end{tabular}
Source : Maping of Creative Industry Study,Ministry of Commerce of the Republic of Indonesia, 2007

Figure 1 Average Labor Productivity in 14 Creative Industry Subsector

Information technology can be classified into three major groups: (1) Physical infrastructure such as the International Access, Domestic Backbone (Inter-city), Inner-city wireline connections, Broadband Wireless Access, Mobile Access Network, IP Convergence Network, and others. (2) Support services or connections such as: Mobile Access, Broadband Fixed Access, Internet Access, Digital Broadcast, etc. (3) Software (Pperating systems, applications, databases, etc.) and hardware (personal computers, laptops, modems, etc.).

Recent conditions are inequality of information technology and communication advances between regions is still relatively large, better telecommunications, more affordable rates, cheaper mobile phones and more internet access providers.

Internet penetration is still low that stymie creative product consumption. Indonesian Internet Service Providers Association (APJII) noted that Internet users by the end of 2007 only about 25 million users or only about $8.5 \%$ of the total population. The low internet penetration may not be a meeting between the creators and consumers of creative products on the market that relies on the Internet as a medium for delivery or consumption, especially in terms of commercialization and distribution.

\begin{tabular}{l|l} 
Indicator & \multicolumn{1}{l}{ Amount } \\
\hline ISP (Internet Service Provider) & 274 company \\
Internet Café & 4.000 place \\
Internet Exchange & 6 points \\
International Trafic & $5 \mathrm{Gbps}$ \\
Internet Exchange Trafic & $80 \mathrm{Gbps}$ \\
Internet User (2007) & 25 Million People \\
Target in 2008 & 40 Million People \\
\hline Source: APJII, the Directorate General of Post \& Telecomunication, APTIKOM, etc
\end{tabular}

Figure 2 Data Statistics Indonesia Internet Industry 2008 
The role of industry associations and professional associations need to be developed. Almost in all sectors of the creative industries are already a member of entrepreneurs or industry associations. They have been trying to serve their interests, but in fact there are more functions that can be played and that is a community of practice. This creative community will be a place sharing knowledge, creativity and experience among creative workers. The need for financing for creative industries is relatively insufficient. Most of the sub-sectors of creative industries do not require a large initial capital to start a business since the creative industry is highly dependent on individual creativity. However, the industry still needs financial assistant to always be creative in creating new product/service to the consumers.

In Indonesia, there are not many financial institutions that offer loans and payment schemes suitable for those in the creative industries. Terms of the collateral on a conventional loan scheme to burden the creative industries but it does not motivate the actors to create something new since the overall risk should be borne by businesses. Creative industries may be able to take advantage of financing schemes People's Business Credit (KUR), which has been launched by the President of Republic of Indonesia on November 5, 2007 by a memorandum of understanding (MoU) between the government, insurance companies, and banks (Bank Mandiri, BNI, BTN, BRI, Bank Bukopin, and Bank Syariah Mandiri) on October 9, 2007 on guaranteeing credit/financing to SMEs/Cooperative.

It is implemented in accordance with the Presidential Decree No. 6 of 2007 dated June 8, 2007 on accelerating the development of the real sector policies and the empowerment of SMEs. But in reality, this policy has not been fully implemented and properly socialized for SMEs or entrepreneurs in need.

Lack of mastery of technology by Indonesian creative workers and the low computer literacy in Indonesia affect the quality of the product creation and commercialization capabilities/services of creative industry in Indonesia. In this digital era, almost all layers of society activities are supported by a technology called computer.

\section{Interactive Gaming Industry Value Chain}

Creative industries prioritize design in the creation of products with limited production volume and require individual creativity as a primary input in the process of value creation. Understanding of the value creation chain in the creative industries creative industry can help stakeholders to understand the position of the creative industries in a series of industry-related creative industries.

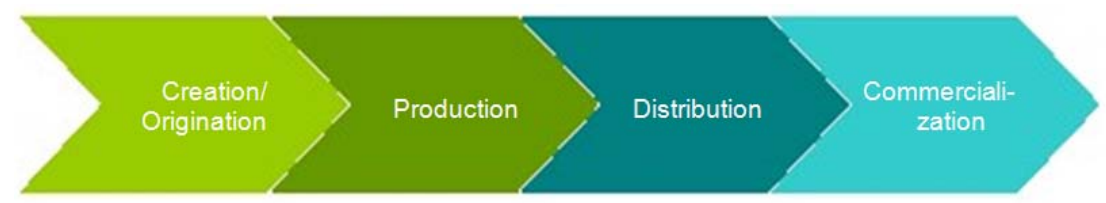

Figure 3 Generic Value Chain Creative Industries

Value chain is the subject of attention in determining the development strategy and it has a linear sequence of creation, production, distribution and commercialization. Creation/Originality is the creation where creativity is a factor of supply/input in the creative industries by involving all matters relating to ways of getting input, store and process, therefore the power of creativity, skill and talent, originality is a factor of supply/input is most important. 
As a product of unique, different and original, it is able to compete with products rival with potentially creating jobs and prosperity for those who have it and also the opposite. Creativity is the power that comes from within the individual. Everyone has the same basic capital but there is a difference in sharpening and making it work, especially for those who is only utilizing a hobby. Today, creativity-based industries are into thriving industry that does not regards creativity as trivial or only a mere sideline.

Production is any activity that is required for transforming inputs into outputs, in the form of products or services. Important factors in a production process is technology. Technology can be divided into core technology and second layer technology. Technology is the most important part and this technology is useful for experiments, research, testing and manufacture in the form of studio and workshop facilities. Both coating technology is the technology that the process could be transferred to third parties with the principle of flexibility: (1) Flexible Manufacturing Systems (Flexible Manufacturing System). (2) Manufacturing Systems Agile (Agile Manufacturing System). (3) Manufacturing Systems Based on the Needs (Just-in-time Manufacturing System). (4) Original Equipment Manufacturer (OEM).

Distribution is any activity in the storage and distribution of output. Important factors in a distribution process: (1) Negotiations Distribution Rights. Negotiations for the creative industry, the products are virtual (intangible) and requires a certain skill. Since this type of product easily change the ownership, without sufficient knowledge and be one-sided negotiations, others will be more profitable than the creator. (2) Internationalization. This activity can be done by following the mainstream market or with a more independent international network. (3) Infrastructure. Developed infrastructure is expected to support the dissemination of the new media (internet), the strengthening of creative people, and the creation of creative clusters.

Commercialization is any activity to give the knowledge to buyers about the products and services provided and also influence the consumer to purchase. Important factors in the distribution process is a marketing (includes imaging, branding, targeting and positioning), sales (including direct selling, leasing/renting, Saas (Software as a service), free (with revenue from virtual merchandising), promotion (includes exhibitions, performances, exploration of new media channel). After Sales Services is the activities required to keep an item or service is still functioning properly in accordance with the expectations of the consumer after the goods or services purchased.

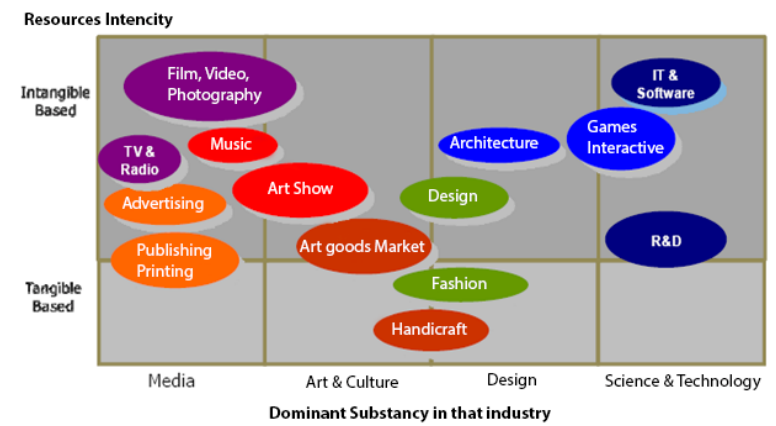

Figure 4 Creative Industry Subsector Classification

Based on the classification matrix (Figure 4) above, sub-grouped by the same color will require a similar development strategy due to the similarity of characteristics, both from the aspect of human resources and the substance to be developed. This research group specializing in the creative industry sector with charge technology (Creativity with Technology): Research and Development subsector, subsector Interactive Games and Information Technology Software Services. 


\section{CONCLUSION}

Based on the results, it is concluded that the implementation of ICT strategies by entrepreneurs in the interactive games industry is still less and this is partly because in general the industry is still small-scale and micro enterprises, mash the industry is relatively new in the world of business, and entrepreneurs are still concentrating the creation, production, and distribution are being developed, and commercialization.

In general, interactive games industry is growing. It takes the role and concrete actions of academics, entrepreneurs, and government in order to develop interactive games industry. In the creative industries, the value chain includes the creation, production, distribution and commercialization. ICT strategies must be implemented in the entire value chain, so that the integration of information systems can be achieved in order to improve efficiency and effectiveness, and improve competitiveness against competitors.

Therefore the entrepreneur should prepare ICT strategy implementation plan and conduct its application. Entrepreneur can use strategic analysis tools such as SWOT, BCG Matrix, IT Balanced Scorecard. To face the challenges of interactive gaming business in the future, it needs to research business model and business strategy, so it would complement the models in the game interactive industry strategy.

\section{REFERENCES}

Kelompok Kerja Indonesia Design Power. (2008). Buku Pengembangan Ekonomi Kreatif Indonesia 2025-Rencana Pengembangan Ekonomi Kreatif Indonesia 2009 - 2015. Studi Industri Kreatif Indonesia. Departemen Perdagangan RI.

Manktelow, J. (2010). The Boston Matrix: Focusing Effort to Give the Greatest Returns. Diakses pada 20 Mei 2012 dari http://www.mindtools.com/pages/article/newTED_97.htm

Moloeng, L. J. (2004). Metode Penelitian Kualitatif. Bandung: Rosda.

Sampoerna foundation. (2009). Creative Industry Development. Diakses pada 20 Mei 2012 dari http://www.sampoernafoundation.org/content/view/1457/342/lang,id/

Ward, J., Peppard. J. (2002). Strategic Planning for Information Systems. (3 edition). John Wiley \& Sons.

Winarto V. (2003, 30 January). Entrepreneurship: Semangat untuk memberikan solusi bagai

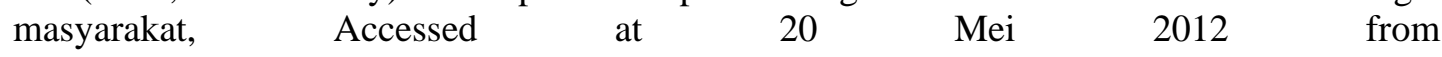
http;//www.epsikologi.com/pengembangan/rls.htm 